\title{
Conjunctival Melanoma: Genetic and Epigenetic Insights of a Distinct Type of Melanoma
}

\author{
Ernesto Rossi ${ }^{1, *} \oplus$, Giovanni Schinzari ${ }^{1,2}$, Brigida Anna Maiorano ${ }^{1}$, Monica Maria Pagliara ${ }^{3}$, \\ Alessandro Di Stefani ${ }^{4} \mathbb{D}^{-}$, Emilio Bria ${ }^{1,2}{ }^{\mathbb{D}}$, Ketty Peris ${ }^{4}$, Maria Antonietta Blasi ${ }^{3}$ and \\ Giampaolo Tortora ${ }^{1,2}$ \\ 1 Medical Oncology, Fondazione Policlinico Universitario Agostino Gemelli IRCCS, 00168 Rome, Italy; \\ giovanni.schinzari@unicatt.it (G.S.); brigim@hotmail.it (B.A.M.); emilio.bria@unicatt.it (E.B.); \\ giampaolo.tortora@policlinicogemelli.it (G.T.) \\ 2 Medical Oncology, Università Cattolica del Sacro Cuore, 00168 Rome, Italy \\ 3 Ophtalmology, Fondazione Policlinico Universitario Agostino Gemelli IRCCS, 00168 Rome, Italy; \\ monicamaria.pagliara@policlinicogemelli.it (M.M.P.); mariaantonietta.blasi@unicatt.it (M.A.B.) \\ 4 Dermatology, Fondazione Policlinico Universitario Agostino Gemelli IRCCS, 00168 Rome, Italy; \\ alessandro.distefani@gmail.com (A.D.S.); ketty.peris@unicatt.it (K.P.) \\ * Correspondence: ernesto.rossi@policlinicogemelli.it; Tel.: +39-06-30156318
}

Received: 24 September 2019; Accepted: 28 October 2019; Published: 31 October 2019

\begin{abstract}
Conjunctival melanoma $(\mathrm{CjM})$ is a rare, primary cancer of the ocular region. Genetic and epigenetic characteristics of conjunctival melanoma have not been completely elucidated yet. Conjunctival melanoma presents similarities with cutaneous melanoma, with substantial differences in the biological behavior. We reviewed the genetic and epigenetic insights of CjM involved in invasion and metastatic spread. CjM is commonly characterized by mutations of v-raf murine sarcoma viral oncogene homolog B1 (BRAF), neurofibromin 1 (NF1) and telomerase reverse transcriptase (TERT), high expression of mammalian target of rapamycin (mTOR) and heat shock protein 90 (HSP90), frequent phosphatase and tensin homolog (PTEN) loss and upregulation of specific miRNAs. These features should identify CjM as a distinct subset of melanoma with its own profile, which is more similar to cutaneous melanoma than mucosal melanoma and remarkably different from uveal melanoma.
\end{abstract}

Keywords: conjunctival; melanoma; BRAF; NRAS; NF1; EZH2; miRNA; genetic

\section{Introduction}

Conjunctival melanoma (CjM) constitutes $5 \%$ of all ocular melanomas. It originates from melanocytes in the basal layer of the epithelium of the conjunctival membrane [1-3]. The incidence of CjM in Europe and the US is around 0.2-0.7 cases per million annually and this disease predominantly affects Caucasians and the elderly, while it is rare among children [3-14]. Primary acquired melanosis 'PAM' with atypia is responsible for up to $60 \%$ of conjunctival melanomas, with a transformation risk of about $13 \%$ [15-19]. 'PAM', also indicated as 'conjunctival melanocytic intraepithelial neoplasia' or 'intraepithelial melanocytic proliferation', presents as an acquired brown pigmentation of the conjunctiva [19]. CjM can be preceded by conjunctival nevi, which develop into melanomas in $<7 \%$ of the cases [20]. CjM may also occur 'de novo' in about $19 \%$ of the cases $[9,15,16]$. It usually presents with pigmented lesions that are most commonly located on the bulbar conjunctiva (Figure 1) (92\%) and, in over $60 \%$ of cases, it affects the temporal quadrants. Less frequently affected are the palpebral and forniceal conjunctiva, plica semilunaris and caruncula, which have the worst prognosis $[9,15,21-23]$. Conjunctival melanomas are multifocal in about $30 \%$ of the cases [21]. Occasionally, lesions of CjM 
are unpigmented [22]. CjM shows a five-year local recurrence rate from $26 \%$ to $61 \%[9,15,21,23,24]$. Non-epibulbar lesions have the highest risk of local recurrence [14,15]. CjM spreads directly towards the orbit or through lymphatic and hematic vessels [15,25]. Temporal CjM diffuses to the pre-auricular lymph nodes, whereas the submandibular lymph nodes are usually involved in cases of nasal CjM [26]. Distant metastases are frequently found in the liver, lungs, skin and brain [9,15]. Tumors with a nodular growth pattern, recurrent lesions and 'de novo' CjM have the highest risk of metastatic spread [21,23]. CjM has a 10-year mortality rate of approximately $30 \%[3,5,6,8,15,22,27]$.

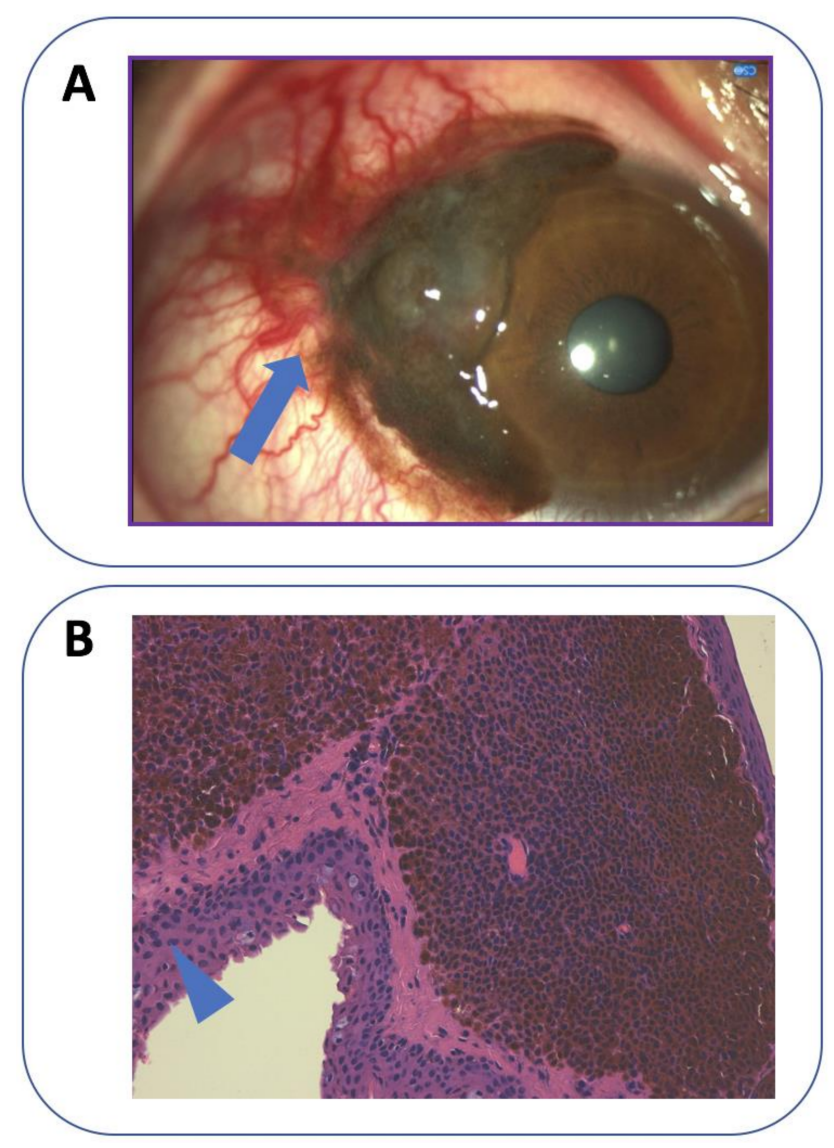

Figure 1. Clinical and histological appearance of melanoma of the bulbar conjunctiva. (A) A pigmented elevated, vascularized lesion (arrow) with feeder vessels located in the temporal bulbar conjunctiva and in the limbus. It originated in the conjunctival epithelium and gradually grew over the cornea. (B) Histological appearance of the lesion in (A). Dense cohesive sheets of rounded cells with varying pigmentation can be seen in the stroma, constituting a conjunctival melanoma. The overlying epithelium has normal appearance (arrowhead). Original magnification $200 \times$ - courtesy of Vincenzo Fiorentino, Pathology Department, Fondazione Policlinico Universitario Agostino Gemelli IRCCS).

Genetic and epigenetic features of CjM have not been extensively elucidated to date. Some risk factors, such as sunlight exposure, and some genetic alterations are typical of both cutaneous and conjunctival melanoma. V-raf murine sarcoma viral oncogene homolog B1 (BRAF) V600E mutation characterizes up to $50 \%$ of conjunctival melanomas as an early event in tumor development [1-3,28-34]. NF1 mutations can be detected in about $30 \%$ of conjunctival melanomas [35]. Neuroblastoma RAS viral [v-ras] oncogene homolog (NRAS) mutations occur in about $20 \%$ of the cases and are mutually exclusive with BRAF mutations [29,32,33,36,37]. KIT mutations are more seldomly detected (lower than 7\%) and are mutually exclusive with NRAS and BRAF mutations [31,36-38]. Oncogenic signaling altered in CjM includes both MAPK and PI3K pathways. As a matter of fact, phosphorylated active forms of proteins belonging to the PI3K/AKT pathway and its downstream effector mTOR are frequently overexpressed in CjM cells, while decreased levels of phosphatase and tensin homolog 
(PTEN)—inhibiting PI3K/AKT/mTOR cascade-occur in this disease [39,40]. Furthermore, an increased telomerase activity with TERT promoter mutations can be found in about $40 \%$ of conjunctival melanomas [41,42]. In addition, molecular features of this tumor may also include the overexpression of HSP90 and Bcl-2, the inactivation of p16, other minor chromosome abnormalities and miRNAs upregulation [43-46]. However, none of these genetic or epigenetic alterations seems to have a prognostic role in CjM.

This review aims to elucidate in detail the genetic and epigenetic features of $\mathrm{CjM}$ involved in invasion and metastatic spread in order to identify potential therapeutic targets for this disease. Moreover, we aim to point out that CjM could be identified as a distinct subset of melanoma with specific genetic and epigenetic alterations that are not completely shared with other types of melanoma, such as cutaneous, mucosal or uveal melanoma (Figure 2).

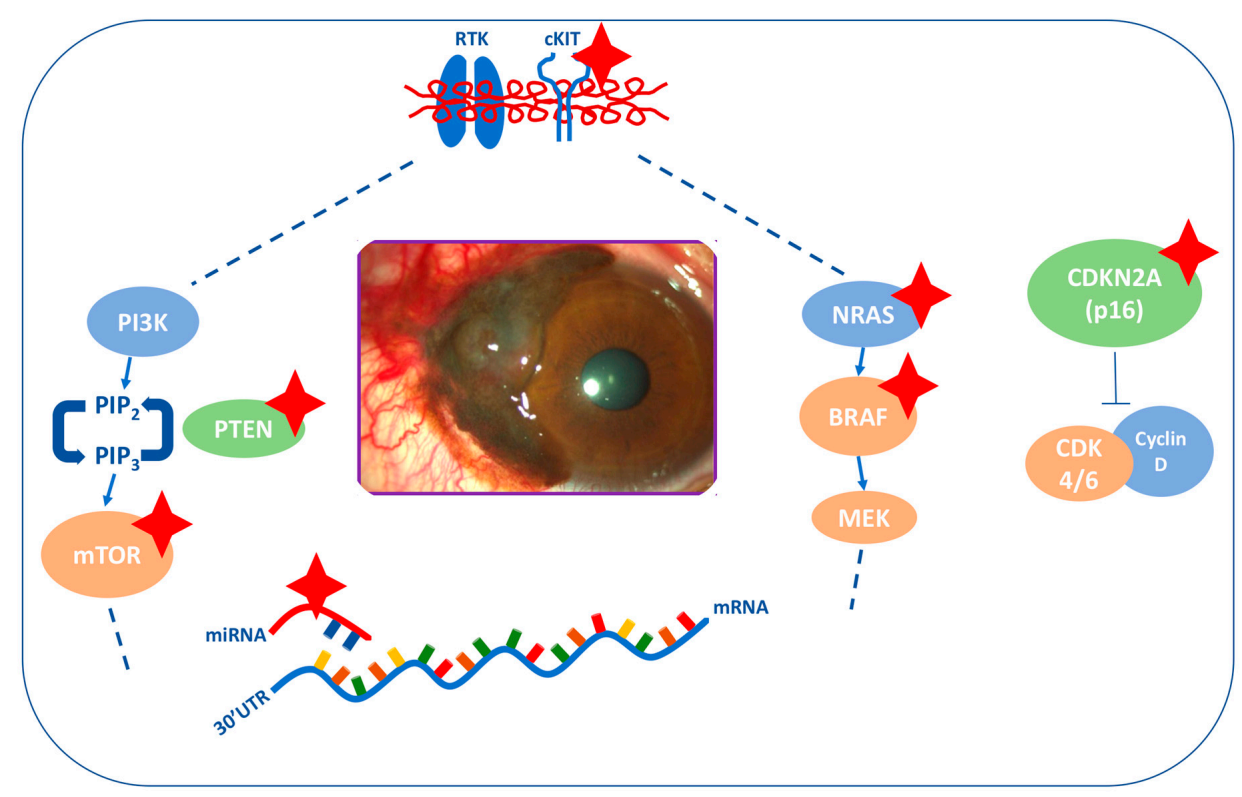

Figure 2. Main mechanisms involved in conjunctival melanoma (CjM). The most relevant alterations are indicated with red stars. $B R A F$ and NRAS mutations are mutually exclusive. $c K I T$ mutations are mutually exclusive with $B R A F / N R A S$ mutations.

\section{Methods}

The literature search was performed using electronic databases (Pubmed, Scopus and Web of Science) and selected keywords (such as "conjunctival melanoma", "genetic", "pathway"), linked with the Boolean operator "AND" and "OR". Reference list of the articles was manually screened to find other relevant papers through the snowball search technique. A total of 950 full-length papers, including original researches, case reports and reviews, were identified. All the articles regarding genetic and epigenetic of $\mathrm{CjM}$ were considered. Papers dealing with the most important pathways involved in cutaneous, mucosal and uveal melanoma were also selected.

\section{Genetic and Epigenetic Features of Conjunctival Melanoma}

CjM has several molecular alterations associated with malignant transformation, invasion and distant spread. RAS-RAF-MEK-ERK is one of the pathways more frequently dysregulated in CjM [28]. This pathway transfers the signal from the plasmatic membrane to the nucleus, activating transcriptional factors and regulating gene expression [47]. In CjM, its activation most commonly depends on $B R A F$, NRAS or KIT mutations [48]. The frequency of BRAF, NRAS and KIT mutations in CjM is more similar to cutaneous melanoma than uveal/mucosal melanoma [28,29,38,48-51]. 


\subsection{BRAF}

$B R A F$ mutations have been detected in up to $50 \%$ of primary and metastatic conjunctival melanomas as in cutaneous melanoma [1-3,28-34,51]. About $80-90 \%$ of the mutations are represented by the V600E (substitution of valine with glutamic acid, at aminoacid 600) [33,51]. The second most common mutation is V600K (substitution of valine with lysine, at aminoacid 600) [51]. Other uncommon $B R A F$ mutations are detectable in $<6 \%$ of conjunctival melanomas [52]. These BRAF mutations found in $\mathrm{CjM}$ are similar to cutaneous melanoma, in which V600E represents the most typical mutation (almost $70 \%$ of cases), followed by V600K (about $20 \%$ of cases) and less frequent mutations, such as V600D and V600R [52]. Acral and mucosal melanomas more rarely harbor BRAF mutations (respectively, 10-15\% and $5 \%$ of cases) [53,54], which, on the contrary, have never been reported in uveal melanoma [55].

$B R A F$ mutations are frequently associated with melanocytic nevi (up to $67 \%$ ) and probably occur in early stages of CjM development from nevi [31-33]. Indeed, up to 50\% of conjunctival nevi harbor $B R A F$ mutations, which are less common in PAM [31,40].

$B R A F$-mutant conjunctival melanomas usually occur in young males and present with pigmented cells more frequently than $B R A F$ wild-type conjunctival melanomas [51,56]. Similarly, in cutaneous melanoma $B R A F$ mutations are more predominant among younger patients [57]. Moreover, $B R A F$-mutant conjunctival melanomas are more common on the bulbar than extrabulbar conjunctiva. This higher incidence of $B R A F$ mutations in the bulbar region of the eye, more exposed to sunlight, identifies UV radiations as a possible risk factor for this disease [31-33].

BRAF mutations are not significantly associated with increased recurrence, regional metastases or mortality from CjM, but they are correlated with reduced distant metastases free-survival [33,51].

In vitro, Vemurafenib and Dabrafenib inhibit BRAF-mutant CjM cell lines, similarly to cutaneous melanoma cells [40]. In vivo, several $B R A F$ mutated conjunctival melanomas were effectively treated with BRAF inhibitors in monotherapy or in combination with MEK inhibitors [58-63]. Thus, as patients with BRAF-mutant cutaneous melanoma are successfully treated with combined BRAF/MEK inhibitors, it can be hypothesized that CjM patients might also benefit from these agents. In conclusion, we believe that tests for BRAF mutations should be included in the management of CjM and that clinical studies with BRAF and MEK inhibitors are required in this setting [64].

\subsection{NRAS}

The NRAS gene encodes N-ras, a GTPase protein, which is involved in the regulation of cellular division [31]. NRAS mutations have been found in almost $20 \%$ of conjunctival melanomas [31,38,40,44,45]. Regarding the other types of melanoma, NRAS mutations have been found in about $20 \%$ of cutaneous melanomas, $5-13 \%$ of mucosal melanomas and $10 \%$ of acral melanomas. NRAS mutations have not been detected in uveal melanomas [65]. It is worth noting that benign cutaneous nevi can harbor NRAS mutations [66,67].

In CjM, NRAS mutations are mutually exclusive with $B R A F$ mutations [31,38,40,44,45], similarly to cutaneous melanoma, in which concomitant $B R A F$ and NRAS mutations occur in less than $0.6 \%$ of cases [68].

\subsection{KIT}

c-KIT mutations have been detected in almost $2-7 \%$ of conjunctival melanomas and they are mutually exclusive with NRAS and BRAF mutations, as in cutaneous melanoma [32,36,38,62]. Similarly, in cutaneous melanomas, the incidence of KIT mutations ranges from $5.1 \%$ for non 'sun-exposed' patients to $9.8 \%$ for chronically 'sun-exposed' patients. KIT mutations are more frequently detected in mucosal (about $11.5 \%$ of cases) and acral (10.8\% of cases) melanomas while they have not been reported in uveal melanoma [69]. Overall, KIT mutations show a significant association with older age [70]. 
It has been reported that different ethnic groups express different rates of mutations: $\mathrm{CjM}$ of Chinese people expresses a higher level of KIT mutations (11\%), but a lower rate of BRAF mutations (8\%) than Caucasian people [50].

It is noteworthy that KIT mutations are not directly correlated with KIT gene copy number or CD117, the KIT gene product, expression. Furthermore, not all KIT regions are sensitive to pharmacological inhibition [71-75]. Consequently, we can assume that not all KIT mutations are drivers in melanomas and are not principal therapeutic targets. Partial responses to KIT inhibitors have been observed in less than $20 \%$ of patients with acral, mucosal and chronically sun-damaged melanoma patients, reporting a median overall survival of 46 weeks with imatinib and 7.5 months with dasatinib $[74,75]$.

\subsection{NF1}

The Neurofibromin 1 (NF1) gene (17q11.2) encodes neurofibromin 1, which inhibits the Ras protein through the hydrolysis of Ras-bound GTP $[76,77]$. NF1 mutations, leading to neurofibromin 1 dysfunction, occur in up to $30 \%$ of $\mathrm{CjM}$ and can be found simultaneously with $B R A F$ and $R A S$ mutations [35]. This co-occurrence has been also detected in cutaneous melanoma [78-80]. On the contrary, the co-mutation of NF1 and KIT has not been demonstrated in CjM, while it has been detected in up to $32 \%$ of mucosal melanoma [81].

NF1 mutations are particularly frequent in CjM that have been exposed to UVs, highlighting the possible pathogenetic role of sunlight exposure [79,82,83]. NF1 mutations are associated with sunlight exposure also in cutaneous melanoma and are more frequent in the desmoplastic subtype. It has been demonstrated that cutaneous melanomas with NF1 mutations harbor a higher mutational load. This finding, if confirmed in $\mathrm{CjM}$, could help to identify tumors which are more responsive to immunotherapy (Figure 3A) [20,84].

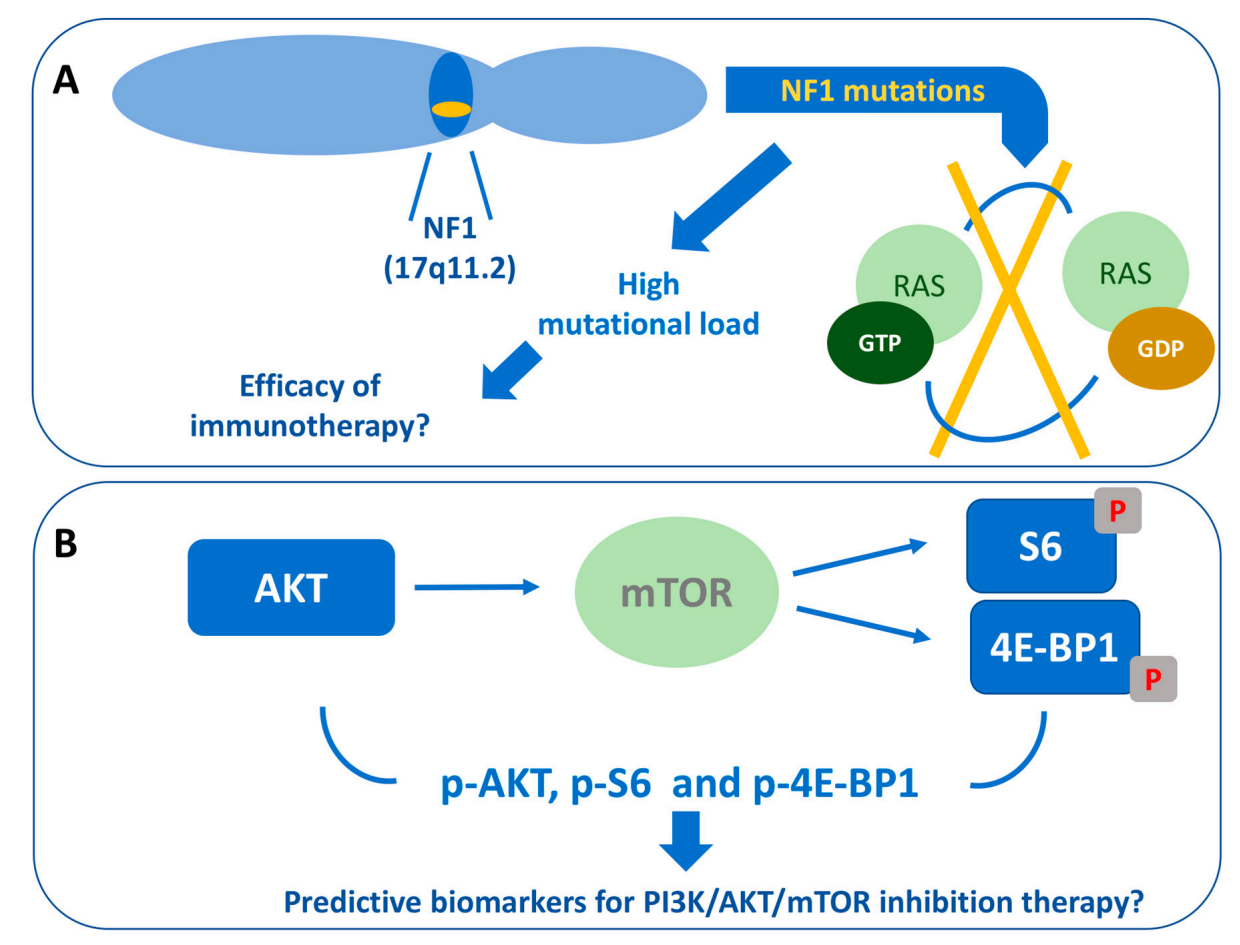

Figure 3. Potential molecular predictive factors for immunotherapy or target therapy in conjunctival melanoma. (A) NF1 (17q11.2) mutations, which cause the loss of RAS-bound GTP hydrolysis, are associated with high mutational load and could help to predict the efficacy of immunotherapy; (B) High levels of AKT, phosphorylated S6 and 4E-BP1 are related to mTOR mutation and could predict the efficacy of PI3K/AKT/mTOR inhibition therapy. 


\subsection{PI3K/AKT/mTOR Pathway}

The PI3K/AKT/mTOR signaling pathway regulates several cellular functions, such as proliferation, metabolism, angiogenesis and metastatic spread [85]. Activated tyrosine kinase receptors (RTK), G protein-coupled receptors (GPCR) or constitutively activated Ras induce PI3K function. Class IA PI3Ks modify phosphatidylinositol-4,5-bisphosphate (PIP2) into phosphatidylinositol-3,4,5-trisphosphate (PIP3), that provides binding sites for PDK1 and mTORC2 (PDK2). These kinases activate AKT through the phosphorylation of its residues Threonine-308 (Thr308) and Serine-473 (Ser473). Factors such as PTEN antagonize AKT activation, whereas other factors, including HSP90, positively regulate AKT. After the activation, AKT phosphorylates many cytoplasmic proteins involved in cell growth and survival [85]. AKT downstream effects are mediated by mTOR, which is part of two complexes: mTORC1 and mTORC2. AKT activates mTORC1 which, in turn, inactivates the translational inhibitor 4E-BP1 and activates the kinase S6, leading to protein synthesis. mTORC2 is capable of directly activating AKT through the phosphorylation of Ser473 [85-87].

Activation of PI3K/AKT/mTOR pathway, confirmed by a high expression of phosphorylated AKT, S6, and 4E-BP1, has been reported in CjM [39]. High expression of mTOR has been found in the cytoplasm of $87 \%$ of CjM cells, and its phosphorylated form (Ser2448) in the cytoplasm and nuclei in $75 \%$ of cells. S6 and its phosphorylated form (Ser235/236) are expressed in 100\% and 75\% of CjM cells, respectively. The expression of 4E-BP1 and its phosphorylated form (Thr37/46) is predominantly cytoplasmic [39]. p-AKT Ser473 is mostly represented in the nuclei, while p-AKT Thr308 is both nuclear and cytoplasmic [40].

In cutaneous melanoma, the PI3K-AKT pathway is involved mostly in tumor initiation and resistance to treatments [88]. The association between mTOR nonsynonymous mutations and a short survival has been reported in cutaneous and mucosal melanoma patients [89]. In mTOR mutant cell lines, high levels of phosphorylated S6, AKT and 4E-BP1 have been found. In this context, the inhibition of PI3K/AKT/mTOR pathway exerted an antiproliferative effect [89]. Thus, the predictive value of high levels of AKT, phosphorylated S6 and phosphorylated 4E-BP1 for PI3K/AKT/mTOR inhibition therapy in CjM patients should be investigated in future studies (Figure 3B).

\subsection{PTEN}

Expression of PTEN, which is an AKT/mTOR pathway inhibitor, is low in CjM [39]. This observation strengthens the hypothesis that the mTOR pathway plays an important role in CjM development [39]. PTEN can be found in different cell compartments such as the cytoplasm and nucleus. The nuclear PTEN plays an oncosuppressive role [90,91]; it is abrogated in neoplastic cells by nuclear-cytoplasmic shuttling. Indeed, the nuclear fraction of PTEN is particularly low in CjM cells [43]. Loss of PTEN has also been observed in about $65 \%$ of cutaneous melanomas [92], while the lack of PTEN immunostaining has been reported in only $16 \%$ of uveal melanoma [93]. The hypothesis that a low expression of PTEN could allow the response to therapies with mTOR inhibitors in CjM patients should be evaluated in further studies [39].

\section{Other Genetic Features of Conjunctival Melanoma}

\subsection{HSP90}

Heat shock protein (HSP)90, a chaperone protein, plays a role in the accurate protein folding and stabilization from stress [94,95]. HSP90 expression is higher in CjM cells than in conjunctival nevi. In particular, HSP90 levels are more elevated in recurrent CjM [43]. This evidence could be particularly important for future therapies targeting specifically HSP90 [96,97]. In cutaneous melanoma HSP90 is also highly expressed, but it does not have a prognostic or predictive value [98]. In uveal melanoma, HSP90 expression has been found, but HSP90 inhibitors did not demonstrate clinical efficacy $[99,100]$. 


\section{2. $B C L-2$}

The B-cell lymphoma 2 (BCL-2) gene family encodes Bcl-2, regulatory proteins which control the mitochondrial response to apoptotic signals to preserve the mitochondrial membrane [101]. Bcl-2 can be considered a marker for melanocytic tumors in the conjunctiva [44]. It has been shown that Bcl-2 levels are remarkably higher in CjM than conjunctival nevi. Surprisingly, there was no significant correlation between Bcl-2 expression and clinical parameters or histopathological characteristics of CjM [43]. In head and neck mucosal melanoma, the high expression of Bcl-2, found in $74 \%$ of the cases, predicted a better survival [102]. Differently, in uveal melanoma the expression of protein-interacting protein 3 (BNIP3), which belongs to the Bcl-2 family, has a negative prognostic significance [103]. High levels of $\mathrm{Bcl}-2$ in cutaneous melanoma are associated with aggressive behavior and metastatic spread and seem to predict chemoresistance [104].

\subsection{TERT}

Telomerase reverse transcriptase (TERT) is a catalytic subunit of the telomerase and is activated by AKT. TERT catalyzes the addition of repetitive sequences in the terminal TTAGGG of chromosomes, preventing the degradation of the chromosomal terminations with an increased cellular division rate. This mechanism leads to cellular immortality $[105,106]$. TERT promoter mutations, which cause an increased TERT expression, are detectable in $32-41 \%$ of conjunctival melanomas and in $8 \%$ of PAM cases. They have not been detected in conjunctival nevi [41,42]. We can assume that the blockage of telomeric loss consequent to TERT promoter mutations leads to a greater stability of the genome. Indeed, while several conjunctival melanocytic nevi harbor BRAF mutations, TERT promoter mutations are detectable only in melanomas and premalignant lesions (such as PAM with atypia), playing a role in tumor progression. TERT promoter mutations detected in CjM consist of $\mathrm{C}>\mathrm{T}$ or $\mathrm{CC}>\mathrm{TT}$ nucleotide changes. These alterations can be considered a typical ultraviolet (UV) effect, suggesting the potential role of UV in inducing genetic alterations involved in the pathogenesis of CjM $[107,108]$. The occurrence of TERT promoter mutations in $\mathrm{CjM}$ is similar to cutaneous melanoma in which TERT mutations can be found in $64-68 \%$ of lesions, both in primary and metastases, and are associated with a shorter survival $[41,109,110]$. To date, no specific prognostic role of TERT promoter mutations has been described in CjM. Acral and mucosal melanomas harbor TERT alterations respectively in up to $41 \%$ and $8 \%$ of the cases [111,112]. The detection of TERT promoter mutations reveals future therapeutic options for CjM. Thus, reverse transcriptase inhibitors, such as azidothymidine (AZT), may become possible candidates for therapies directed against TERT-promoter mutant conjunctival melanomas (Figure 4A). Imetelstat (GRN163L) is a telomerase inhibitor, which inhibits TERT promoter activity [113]. Other telomerase inhibitors (e.g., MST-312, TmPyP4, BIBR1532, b-rubromycin, PIPER $\{\mathrm{N}, \mathrm{N}$-0-bis-[2-(1-piperidino)-ethyl]-3,4,9,10-tetracarboxylic-diimide $\}$ ) have been also developed and warrant further evaluation in CjM patients [114]. 


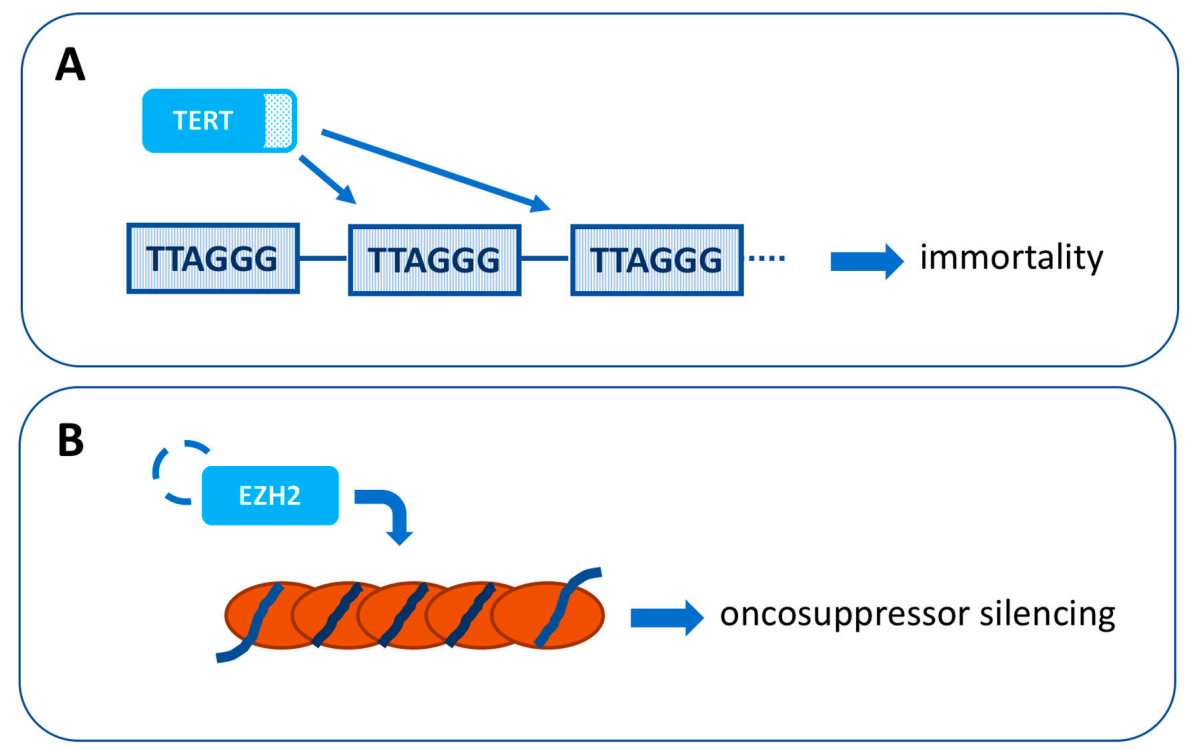

Figure 4. New potential therapeutic targets for conjunctival melanoma. (A) Telomerase reverse transcriptase (TERT) is a catalytic subunit of the telomerase enzyme that catalyzes the addition of repetitive sequences in the terminal TTAGGG of chromosomes. TERT promoter mutations, which cause an increased TERT expression, are detectable in $32-41 \%$ of conjunctival melanomas. (B) Enhancer of zeste homolog $2(\mathrm{EZH} 2)$ is a histone methyltransferase which catalyses trimethylation of lysine 27 in histone $\mathrm{H} 3$ (H3K27me3), leading to transcriptional silencing of oncosuppressors. EZH2 is highly expressed in $50 \%$ of primary conjunctival melanomas and $88 \%$ of lymph node metastases.

\section{4. $C D K N 2 A(p 16)$}

Cyclin-dependent kinase-inhibitor 2A (CDKN2A) gene (9p21.3) encodes p16ink4a (p16) protein, which regulates the cell cycle progression through the inactivation of the complex cyclin-dependent kinase 4/6 (CDK4/6)-cyclin D [115]. p16-inactivating mutations cause the loss of its inhibitory function of CDK4/6-cyclin D complex in the $\mathrm{G} 1$ to the $\mathrm{S}$ phase transition, increasing mitotic activity [115]. CDKN2A mutations can be found both in cutaneous and in CjM $[45,116]$. Furthermore, CDKN2A germline mutations are associated with familiar melanomas $[45,117]$. Acral melanoma expresses mutations of the CDK4/6 pathway in about $82.7 \%$ of the cases [118]. CDKN2A alterations have been also found in mucosal melanoma of the oral cavity, but they are not related to specific clinicopathological subsets [119]. To date, CDKN2A mutations have never been reported in uveal melanoma [120].

CjM show a lower level of nuclear p16 than benign melanocytic lesions and PAMs with atypia. It has also been highlighted that lesions with thickness lower than $2 \mathrm{~mm}$ express higher levels of p16 [45]. In conclusion, we believe that CDKN2A mutations can be of interest as a potential therapeutic target for $\mathrm{CjM}$ and can also be useful for the differential diagnosis between CjM and benign atypical conjunctival nevi [45].

\section{Other Genetic Alterations and Chromosome Abnormalities in Conjunctival Melanoma}

Other genetic alterations have also been identified in CjM but their role in the pathogenesis of this malignancy and their significance as potential therapeutic target require further clarification.

In primary CjM, CDKN1A (encoding p21) and Runt-related transcription factor 2 (RUNX2) genes, both localized on 6p21.2, are frequently amplified [49]. p21 is a tight-binding inhibitor of CDKs and acts as a regulator of the cell cycle at the G1-S checkpoint [121]. RUNX2 encodes a transcriptional factor that is part of the RUNT family, whose role in the metastatic process has already been investigated [122]. Furthermore, metastatic CjM conjunctival melanoma shows the amplification of MLH1 (3p22.1) and TIMP2 (17q25.3) and the deletion of MGMT (20q26.3) and ECHS1 (10q26.3) [49]. The protein encoded by MLH1 is involved in the DNA repair process $[123,124]$. TIMP2 encodes for a matrix metalloproteinase 
that is critical for tissue homeostasis [125]. Deletion of MGMT, which is involved in genome stability, has been detected in many cancer types, including cutaneous melanoma [49]. ECHS1 encodes an enzyme of the fatty acid beta-oxidation, but is also able to interact with STAT3 and has been found altered in many cancer types $[28,49,64]$.

Copy number alterations (CNAs) appear more frequently in BRAF/NRAS wild-type CjM and are principally represented by losses of $1 p, 3 q, 6 q, 8 p, 9 p, 10,11 q, 12 q, 13,15 p$ and $16 q$, and gains of $1 q, 3 p$, $6 p, 7,8 q, 11 q, 12 p, 14 p$ and $17 q[31,126]$. These alterations do not seem to be related to clinical features. The deletion of 10q only was correlated with shorter metastases-free survival, lymphatic invasion and major tumor thickness in 59 CjM patients [126]. Oncosuppressor genes such as NEURL1, PTEN, RASSF4, $D M B T 1, C 10 o r f 90$ and C10orf99 are encoded from this region. Moreover, there is a higher frequency of 10q loss in BRAF mutant CjM [126]. In uveal melanoma, typically BRAF-wild type, the most frequent chromosome abnormalities, such as chromosome 3 monosomy and gain of chromosome $8 \mathrm{q}$, demonstrated a prognostic value for relapse, but they did not predict response to treatment [127].

In CjM the frequency of specific chromosomal alterations varies between groups. About $30 \%$ of $B R A F-$ and $43 \%$ of NRAS-mutant conjunctival melanomas show gains of their oncogenic loci. It is possible that a higher expression of oncogenes could play an important role in the tumorigenesis of this malignancy. Gains of 1q, 3p, and 17q occur more frequently in NRAS-mutant than in BRAF-mutant conjunctival melanomas. The loss of chromosome 10 (including PTEN locus) is principally detected in $B R A F$-mutant CjM. We could assume that tumors with BRAF mutation need a further genetic event, which induces AKT pathway, for their development. On the contrary, this additional event is not necessary for NRAS-mutant CjM, in which the association with chromosome 10 loss is not typical [31].

\subsection{EZH2}

Enhancer of zeste homolog 2 (EZH2) is a histone methyltransferase which catalyzes trimethylation of lysine 27 in histone $\mathrm{H} 3$ (H3K27me3), leading to transcriptional silencing of various genes, including oncosuppressors [128].

In the eye, EZH2 protein expression can be detected in the keratinocytes of normal conjunctiva, but it has not been found in normal conjunctival melanocytes and PAM. EZH2 is highly expressed in $50 \%$ of primary conjunctival melanomas and $88 \%$ of lymph node metastases [46]. High EZH2 is correlated with $\mathrm{CjM}$ thickness and poor prognosis. No correlation was found between overexpression of EZH2 and stage, local or distant relapse and tumor localization. In zebrafish xenografts, genetic and pharmacological knockdown of EZH2, through molecules such as GSK503 or UNC1999, reduces tumor growth and colony formation of CjM cells. Inactivation of EZH2 upregulates the oncogene $p 21 / C D K N 1 A$, that controls cellular transition from the G1 to S phase. Moreover, p21 levels are higher after the genetic than the pharmacological inhibition of EZH2, suggesting that EZH2 can regulate transcription using different pathways in addition to its catalytic activity [46]. Inhibition of EZH2 in CjM cells slows the cellular progression to the S-phase and determines cell death through apoptosis and autophagy. Indeed, it increases both the amount of apoptotic cleaved poli-ADP-ribose polymerases (PARPs) and the expression of LC3B-II (Microtubule-associated proteins 1A/1B light chain 3B), a hallmark of autophagy [46].

In conclusion, EZH2 knockdown in CjM cells leads to an S-phase depletion with G1 arrest and accumulation of cells in the G2/M phase. It derives that EZH2 prevents the death of CjM cells [46]. These findings suggest that higher EZH2 is important for tumorigenesis and progression of CjM. For this reason, EZH2 could become a therapeutic target for CjM. EZH2 overexpression has been confirmed in the other types of melanomas associated with metastatic spread and resistance to treatments [128-130].

The catalytic activity of EZH2 can be inhibited by some small specific target agents: The phase 1-2 clinical trial (NCT 01897571) with tazemetostat has been designed for patients with advanced solid tumors and B-cell lymphoma [46]. Further investigations are required to define the role of EZH2 in CjM development (Figure 4B). 


\section{2. $m i R N A$}

MicroRNAs (miRNAs) are small, non-coding RNA molecules which work as epigenetic regulators causing post-transcriptional silencing of specific genes through the binding to the 30'UTR of their corresponding mRNAs [131,132]. miRNAs can play the role of oncogenes and oncosuppressors and are involved in the pathogenesis of almost all cancer types [131,133,134]. In CjM, several miRNAs are upregulated and could be considered potential prognostic biomarkers or targets for therapy [33]. Upregulated miRNAs have been also found in cutaneous melanoma [135]. MiR-20b-5p (miR-20b) has been described to be upregulated both in CjM and in cutaneous melanoma. This upregulation is responsible for PTEN suppression $[33,136]$. MiR-146a acts in the first phases of cancerogenesis in $B R A F / N R A S$-mutated cutaneous melanoma through NOTCH proteins [137]. The upregulation of miR-146a-5p (miR-146/miR-146a) and miR-146b-5p (miR-146b) has been also reported in CjM [33]. Other miRNAs upregulated both in CjM and cutaneous melanoma are miR-30d-5p (miR-30d), MiR-506-3p (miR-506), miR-509-3p (miR-509) [33,138,139]. The inhibition of miR-509 and miR-506 reduces the capability of CjM cells to grow and invade [35]. The association between the upregulation of mir-3916 and an increased risk of local recurrence of CjM has been pointed out [51]. Some miRNAs are upregulated both in CjM and mucosal melanoma [33]. Other miRNAs are also implicated in uveal melanoma metastatic spread [140].

\section{Conclusions}

Overall, CjM is commonly characterized by mutations of BRAF, NF1 and TERT, high expression of mTOR and HSP90, frequent PTEN loss and upregulation of specific miRNAs. These alterations represent potential therapeutic targets. In particular, it could be useful to test the $B R A F$ mutational status considering the high rate of mutations. The anti-BRAF and anti-MEK combination could be a therapeutic option in case of $B R A F$ mutations [58].

Based on the genetic features, $\mathrm{CjM}$ can be considered more similar to cutaneous than mucosal melanoma and remarkably different from uveal melanoma. Consequently, we can assume that CjM is a distinct type of melanoma.

Being ocular melanomas, both CjM and uveal melanoma are often excluded from clinical trials, despite their diversity. However, taking into account the genetic profile of CjM and its similarities with cutaneous melanoma, the extension to $\mathrm{CjM}$ of the studies proposed for cutaneous melanoma could be encouraged.

While the knowledge of biology has improved over the last years, further information regarding genetic and epigenetic features of $\mathrm{CjM}$ is required to address the best targeted treatments. The challenge for the future is the identification of the driver molecular alterations to achieve a clinically relevant therapeutic effect in CjM patients.

Author Contributions: E.R., G.S., G.T. conceived, planned and wrote the review. B.A.M., M.M.P., A.D.S., E.B., K.P., M.A.B. critically revised the manuscript.

Funding: This research received no external funding.

Conflicts of Interest: The authors declare no conflict of interest.

\section{References}

1. Isager, P.; Engholm, G.; Overgaard, J.; Storm, H. Uveal and conjunctival malignant melanoma in Denmark, 1943-1997: Observed and relative survival of patients followed through 2002. Ophthalmic Epidemiol. 2006, 13, 85-96. [CrossRef] [PubMed]

2. Chang, A.E.; Karnell, L.H.; Menck, H.R. The national cancer data base report on cutaneous and noncutaneous melanoma: A summary of 84,836 cases from the past decade. The American College of Surgeons Commission on Cancer and the American Cancer Society. Cancer 1998, 83, 1664-1678. [CrossRef]

3. Seregard, S. Conjunctival melanoma. Surv. Ophthalmol. 1998, 42, 321-350. [CrossRef] 
4. McLaughlin, C.C.; Wu, X.C.; Jemal, A.; Martin, H.J.; Roche, L.M.; Chen, V.W. Incidence of noncutaneous melanomas in the US. Cancer 2005, 103, 1000-1007. [CrossRef]

5. Norregaard, J.C.; Gerner, N.; Jensen, O.A.; Prause, J.U. Malignant melanoma of the conjunctiva: Occurrence and survival following surgery and radiotherapy in a Danish population. Graefes Arch. Clin. Exp. Ophthalmol. 1996, 234, 569-572. [CrossRef]

6. Seregard, S.; Kock, E. Conjunctival malignant melanoma in Sweden 1969-91. Acta Ophthalmol. 1992, 70, 289-296. [CrossRef]

7. Hu, D.N.; Yu, G.; McCormick, S.A.; Finger, P.T. Population-based incidence of conjunctival melanoma in various races and ethnic groups and comparison with other melanomas. Am. J. Ophthalmol. 2008, 145, 418-423. [CrossRef]

8. Triay, E.; Bergman, L.; Nilsson, B.; All-Ericsson, C.; Seregard, S. Time trends in the incidence of conjunctival melanoma in Sweden. Br. J. Ophthalmol. 2009, 93, 1524-1528. [CrossRef]

9. Shields, C.L.; Shields, J.A.; Gündüz, K.; Cater, J.; Mercado, G.V.; Gross, N.; Lally, B. Conjunctival melanoma: Risk factors for recurrence, exenteration, metastasis, and death in 150 consecutive patients. Arch. Ophthalmol. 2000, 118, 1497-1507. [CrossRef]

10. Yu, G.P.; Hu, D.N.; McCormick, S.; Finger, P.T. Conjunctival melanoma: Is it increasing in the United States? Am. J. Ophthalmol. 2003, 135, 800-806. [CrossRef]

11. Shields, C.L.; Demirci, H.; Karatza, E.; Shields, J.A. Clinical survey of 1643 melanocytic and nonmelanocytic conjunctival tumors. Ophthalmology 2004, 111, 1747-1754. [CrossRef] [PubMed]

12. Taban, M.; Traboulsi, E.I. Malignant melanoma of the conjunctiva in children: A review of the international literature 1965-2006. J. Pediatr. Ophthalmol. Strabismus 2007, 44, 277-282. [PubMed]

13. Polat, A.; Yildirim, C.; Işik Balci, Y.; Ince, T.; Bir, F.; Demirkan, N.; Bican, M. Conjunctival melanoma in a six-year-old female. Pediatr. Blood Cancer 2008, 50, 384-386. [CrossRef] [PubMed]

14. Tuomaala, S.; Eskelin, S.; Tarkkanen, A.; Kivelä, T. Population-based assessment of clinical characteristics predicting outcome of conjunctival melanoma in whites. Investig. Ophthalmol Vis. Sci. 2002, 43, 3399-3408.

15. Missotten, G.S.; Keijser, S.; De Keizer, R.J.; De Wolff-Rouendaal, D. Conjunctival melanoma in the Netherlands: A nationwide study. Investig. Ophthalmol. Vis. Sci. 2005, 46, 75-82. [CrossRef] [PubMed]

16. Shields, J.A.; Shields, C.L.; Mashayekhi, A.; Marr, B.P.; Benavides, R.; Thangappan, A.; Phan, L.; Eagle, R.C., Jr. Primary acquired melanosis of the conjunctiva: Experience with 311 eyes. Trans. Am. Ophthalmol. Soc. 2007, 105, 61-71.

17. Brownstein, S. Malignant melanoma of the conjunctiva. Cancer Control 2004, 11, 310-316. [CrossRef]

18. Kurli, M.; Finger, P.T. Melanocytic conjunctival tumors. Ophthalmol. Clin. N. Am. 2005, 18, 15-24. [CrossRef]

19. Jakobiec, F.A. Conjunctival Primary Acquired Melanosis: Is It Time for a New Terminology? Am. J. Ophthalmol. 2016, 162, 3-19.e1. [CrossRef]

20. Shields, C.L.; Fasiuddin, A.F.; Mashayekhi, A.; Shields, J.A. Conjunctival nevi: Clinical features and natural course in 410 consecutive patients. Arch. Ophthalmol. 2004, 122, 167-175. [CrossRef]

21. Anastassiou, G.; Heiligenhaus, A.; Bechrakis, N.; Bader, E.; Bornfeld, N.; Steuhl, K.P. Prognostic value of clinical and histopathological parameters in conjunctival melanomas: A retrospective study. Br. J. Ophthalmol. 2002, 86, 163-167. [CrossRef] [PubMed]

22. Paridaens, A.D.; McCartney, A.C.; Minassian, D.C.; Hungerford, J.L. Orbital exenteration in 95 cases of primary conjunctival malignant melanoma. Br. J. Ophthalmol. 1994, 78, 520-528. [CrossRef] [PubMed]

23. Shields, C.L.; Markowitz, J.S.; Belinsky, I.; Schwartzstein, H.; George, N.S.; Lally, S.E.; Mashayekhi, A.; Shields, J.A. Conjunctival melanoma: Outcomes based on tumor origin in 382 consecutive cases. Ophthalmology 2011, 118, 389-395.e2. [CrossRef] [PubMed]

24. Werschnik, C.; Lommatzsch, P.K. Long-term follow-up of patients with conjunctival melanoma. Am. J. Clin. Oncol. 2002, 25, 248-255. [CrossRef]

25. Missotten, G.S.; Gambrelle, J.; de Wolff-Rouendaal, D.; de Keizer, R.J. Epistaxis or epiphora as a sign for extension of a conjunctival melanoma. A series of six patients with nasolacrimal recurrence. Br. J. Ophthalmol. 2010, 94, 1328-1331. [CrossRef]

26. Lim, M.; Tatla, T.; Hersh, D.; Hungerford, J. Patterns of regional head and neck lymph node metastasis in primary conjunctival malignant melanoma. Br. J. Ophthalmol. 2006, 90, 1468-1471. [CrossRef]

27. Shildkrot, Y.; Wilson, M.W. Conjunctival melanoma: Pitfalls and dilemmas in management. Curr. Opin. Ophthalmol. 2010, 21, 380-386. [CrossRef] 
28. Spendlove, H.E.; Damato, B.E.; Humphreys, J.; Barker, K.T.; Hiscott, P.S.; Houlston, R.S. BRAF mutations are detectable in conjunctival but not uveal melanomas. Melanoma Res. 2004, 4, 449-452. [CrossRef]

29. Goldenberg-Cohen, N.; Cohen, Y.; Rosenbaum, E.; Herscovici, Z.; Chowers, I.; Weinberger, D.; Pe'er, J.; Sidransky, D. T1799A BRAF mutations in conjunctival melanocytic lesions. Investig. Ophthalmol. Vis. Sci. 2005, 46, 3027-3030. [CrossRef]

30. Gear, H.; Williams, H.; Kemp, E.G.; Roberts, F. BRAF mutations in conjunctival melanoma. Investig. Ophthalmol. Vis. Sci. 2004, 45, 2484-2488. [CrossRef]

31. Griewank, K.G.; Westekemper, H.; Murali, R.; Mach, M.; Schilling, B.; Wiesner, T.; Schimming, T.; Livingstone, E.; Sucker, A.; Grabellus, F.; et al. Conjunctival melanomas harbor BRAF and NRAS mutations and copy number changes similar to cutaneous and mucosal melanomas. Clin. Cancer Res. 2013, 19, 3143-3152. [CrossRef] [PubMed]

32. Kastelan, S.; Gverović Antunica, A.; Orešković, L.B.; Rabatic, J.S.; Kasun, B.; Bakija, I. Conjunctival Melanoma-Epidemiological Trends and Features. Pathol. Oncol. Res. 2018, 24, 787-796. [CrossRef] [PubMed]

33. Larsen, A.C.; Dahmcke, C.M.; Dahl, C.; Siersma, V.D.; Toft, P.B.; Coupland, S.E.; Prause, J.U.; Guldberg, P.; Heegaard, S. A retrospective review of conjunctival melanoma presentation, treatment, and outcome and an investigation of features associated with BRAF mutations. JAMA Ophthalmol. 2015, 133, 1295-1303. [CrossRef] [PubMed]

34. Shields, C.L.; Kaliki, S.; Al-Dahmash, S.A.; Lally, S.E.; Shields, J.A. American joint committee on cancer (AJCC) clinical classification predicts conjunctival melanoma outcomes. Ophthalmic Plast. Reconstr. Surg. 2012, 28, 313-323. [CrossRef]

35. Scholz, S.L.; Cosgarea, I.; Süßkind, D.; Murali, R.; Möller, I.; Reis, H.; Leonardelli, S.; Schilling, B.; Schimming, T.; Hadaschik, E.; et al. NF1 mutations in conjunctival melanoma. Br. J. Cancer 2018, 118, 1243-1247. [CrossRef]

36. Wallander, M.L.; Layfield, L.J.; Emerson, L.L.; Mamalis, N.; Davis, D.; Tripp, S.R.; Holden, J.A. KIT mutations in ocular melanoma: Frequency and anatomic distribution. Mod. Pathol. 2011, 24, 1031-1035. [CrossRef]

37. Wong, J.R.; Nanji, A.A.; Galor, A.; Karp, C.L. Management of conjunctival malignant melanoma: A review and update. Expert Rev. Ophthalmol. 2014, 9, 185-204. [CrossRef]

38. Beadling, C.; Jacobson-Dunlop, E.; Hodi, F.S.; Le, C.; Warrick, A.; Patterson, J.; Town, A.; Harlow, A.; Cruz, F.; Azar, S.; et al. KIT gene mutations and copy number in melanoma subtypes. Clin. Cancer Res. 2008, 14, 6821-6828. [CrossRef]

39. Populo, H.; Soares, P.; Rocha, A.S.; Silva, P.; Lopes, J.M. Evaluation of the mTOR pathway in ocular (uvea and conjunctiva) melanoma. Melanoma Res. 2010, 20, 107-117. [CrossRef]

40. Cao, J.; Heijkants, R.C.; Jochemsen, A.G.; Dogrusöz, M.; de Lange, M.J.; van der Velden, P.A.; van der Burg, S.H.; Jager, M.J.; Verdijk, R.M. Targeting of the MAPK and AKT pathways in conjunctival melanoma shows potential synergy. Oncotarget 2016, 8, 58021-58036. [CrossRef]

41. Griewank, K.G.; Murali, R.; Schilling, B.; Scholz, S.; Sucker, A.; Song, M.; Süsskind, D.; Grabellus, F.; Zimmer, L.; Hillen, U.; et al. TERT promoter mutations in ocular melanoma distinguish between conjunctival and uveal tumours. Br. J. Cancer 2013, 109, 497-501. [CrossRef] [PubMed]

42. Koopmans, A.E.; Ober, K.; Dubbink, H.J.; Paridaens, D.; Naus, N.C.; Belunek, S.; Krist, B.; Post, E.; Zwarthoff, E.C.; de Klein, A.; et al. Prevalence and implications of TERT promoter mutation in uveal and conjunctival melanoma and in benign and premalignant conjunctival melanocytic lesions. Investig. Ophthalmol. Vis. Sci. 2014, 55, 6024-6030. [CrossRef] [PubMed]

43. Westekemper, H.; Karimi, S.; Susskind, D.; Anastassiou, G.; Freistuhler, M.; Steuhl, K.P.; Bornfeld, N.; Schmid, K.W.; Grabellus, F. Expression of HSP 90, PTEN and Bcl-2 in conjunctival melanoma. Br. J. Ophthalmol. 2011, 95, 853-858. [CrossRef] [PubMed]

44. Furusato, E.; Hidayat, A.; Man, Y.G.; Auerbach, A.; Furusato, B.; Rushing, E.J. WT1 and Bcl2 expression in melanocytic lesions of the conjunctiva: An immunohistochemical study of 123 cases. Arch. Ophthalmol. 2009, 127, 964.e9. [CrossRef]

45. Zoroquiain, P.; Fernandes, B.F.; González, S.; Novais, G.N.; Schalper, K.A.; Burnier, M.N., Jr. p16ink4a Expression in Benign and Malignant Melanocytic Conjunctival Lesions. Int. J. Surg. Pathol. 2012, 20, 240-245. [CrossRef] 
46. Cao, J.; Pontes, K.C.S.; Heijkants, R.C.; Brouwer, N.J.; Groenewoud, A.; Jordanova, E.S.; Marinkovic, M.; van Duinen, S.; Teunisse, A.F.A.S.; Verdijk, R.M.; et al. Overexpression of EZH2 in conjunctival melanoma offers a new therapeutic target. J. Pathol. 2018, 245, 433-444. [CrossRef]

47. McCubrey, J.A.; Steelman, L.S.; Chappell, W.H.; Abrams, S.L.; Wong, E.W.; Chang, F.; Lehmann, B.; Terrian, D.M.; Milella, M.; Tafuri, A.; et al. Roles of the Raf/MEK/ERK pathway in cell growth, malignant transformation and drug resistance. Biochim. Biophys. Acta 2007, 1773, 1263-1284. [CrossRef]

48. Dahl, C.; Guldberg, P. The genome and epigenome of malignant melanoma. APMIS 2007, 115, 1161-1176. [CrossRef]

49. Lake, S.L.; Jmor, F.; Dopierala, J.; Taktak, A.F.; Coupland, S.E.; Damato, B.E. Multiplex ligation-dependent probe amplification of conjunctival melanoma reveals common BRAF V600E gene mutation and gene copy number changes. Investig. Ophthalmol. Vis. Sci. 2011, 52, 5598-5604. [CrossRef]

50. Sheng, X.; Li, S.; Chi, Z.; Si, L.; Cui, C.; Mao, L.; Lian, B.; Tang, B.; Wang, X.; Yan, X.; et al. Prognostic factors for conjunctival melanoma: A study in ethnic Chinese patients. Br. J. Ophthalmol. 2015, 99, 990-996. [CrossRef]

51. Larsen, A.C.; Dahl, C.; Dahmcke, C.M.; Lade-Keller, J.; Siersma, V.D.; Toft, P.B.; Coupland, S.E.; Prause, J.U.; Guldberg, P.; Heegaard, S. BRAF mutations in conjunctival melanoma: Investigation of incidence, clinicopathological features, prognosis and paired premalignant lesions. Acta Ophthalmol. 2016, 94, 463-470. [CrossRef] [PubMed]

52. Glitza, I.C.; Davies, M.A. Genotyping of cutaneous melanoma. Chin. Clin. Oncol. 2014, 3, 27. [PubMed]

53. Greaves, W.O.; Verma, S.; Patel, K.P.; Davies, M.A.; Barkoh, B.A.; Galbincea, J.M.; Yao, H.; Lazar, A.J.; Aldape, K.D.; Medeiros, L.J.; et al. Frequency and spectrum of BRAF mutations in a retrospective, single-institution study of 1112 cases of melanoma. J. Mol. Diagn. 2013, 15, 220-226. [CrossRef] [PubMed]

54. Wong, C.W.; Fan, Y.S.; Chan, T.L.; Chan, A.S.; Ho, L.C.; Ma, T.K.; Yuen, S.T.; Leung, S.Y. Cancer Genome Project. BRAF and NRAS mutations are uncommon in melanomas arising in diverse internal organs. J. Clin. Pathol. 2005, 58, 640-644. [CrossRef]

55. Van Raamsdonk, C.D.; Bezrookove, V.; Green, G.; Bauer, J.; Gaugler, L.; O’Brien, J.M.; Simpson, E.M.; Barsh, G.S.; Bastian, B.C. Frequent somatic mutations of GNAQ in uveal melanoma and blue naevi. Nature 2009, 457, 599-602. [CrossRef]

56. Kenawy, N.; Lake, S.L.; Coupland, S.E.; Damato, B.E. Conjunctival melanoma and melanocytic intra-epithelial neoplasia. Eye 2013, 27, 142-152. [CrossRef]

57. Long, G.V.; Menzies, A.M.; Nagrial, A.M.; Haydu, L.E.; Hamilton, A.L.; Mann, G.J.; Hughes, T.M.; Thompson, J.F.; Scolyer, R.A.; Kefford, R.F. Prognostic and clinicopathologic associations of oncogenic BRAF in metastatic melanoma. J. Clin. Oncol. 2011, 29, 1239-1246. [CrossRef]

58. Rossi, E.; Maiorano, B.A.; Pagliara, M.M.; Sammarco, M.G.; Dosa, T.; Martini, M.; Rindi, G.; Bria, E.; Blasi, M.A.; Tortora, G.; et al. Dabrafenib and Trametinib in BRAF Mutant Metastatic Conjunctival Melanoma. Front. Oncol. 2019, 9, 232. [CrossRef]

59. Pahlitzsch, M.; Bertelmann, E.; Mai, C. Conjunctival melanoma and BRAF inhibitor therapy. J. Clin. Exp. Ophthalmol. 2014, 5, 322. [CrossRef]

60. Pinto Torres, S.; André, T.; Gouveia, E.; Costa, L.; Passos, M.J. Systemic treatment of metastatic conjunctival melanoma. Case Rep. Oncol. Med. 2017, 2017, 4623964. [CrossRef]

61. Maleka, A.; Astrom, G.; Byström, P.; Ullenhag, G.J. A case report of a patient with metastatic ocular melanoma who experienced a response to treatment with the BRAF inhibitor vemurafenib. BMC Cancer 2016, 16, 634. [CrossRef] [PubMed]

62. Griewank, K.G.; Westekemper, H.; Schilling, B.; Livingstone, E.; Schimming, T.; Sucker, A.; Hillen, U.; Steuhl, K.P.; Zimmer, L.; Schadendorf, D. Conjunctival melanomas harbor BRAF and NRAS mutations-letter. Clin. Cancer Res. 2013, 19, 6331-6332. [CrossRef] [PubMed]

63. Dagi Glass, L.R.; Lawrence, D.P.; Jakobiec, F.A.; Freitag, S.K. Conjunctival melanoma responsive to combined systemic BRAF/MEK inhibitors. Ophthalmic Plast. Reconstr. Surg. 2017, 33, e114-e116. [CrossRef] [PubMed]

64. Mor, J.M.; Heindl, L.M. Systemic BRAF/MEK Inhibitors as a potential treatment option in metastatic conjunctival melanoma. Ocul. Oncol. Pathol. 2017, 3, 133-141. [CrossRef] [PubMed]

65. Cruz, F., 3rd; Rubin, B.P.; Wilson, D.; Town, A.; Schroeder, A.; Haley, A.; Bainbridge, T.; Heinrich, M.C.; Corless, C.L. Absence of BRAF and NRAS mutations in uveal melanoma. Cancer Res. 2003, 63, 5761-5766. 
66. Colombino, M.; Capone, M.; Lissia, A.; Cossu, A.; Rubino, C.; De Giorgi, V.; Massi, D.; Fonsatti, E.; Staibano, S.; Nappi, O.; et al. BRAF/ NRAS mutation frequencies among primary tumors and metastases in patients with melanoma. J. Clin. Oncol. 2012, 30, 2522-2529. [CrossRef]

67. Yeh, I.; Bastian, B.C. Genome-wide associations studies for melanoma and nevi. Pigment Cell Melanoma Res. 2009, 22, 527-528. [CrossRef]

68. Jakob, J.A.; Bassett, R.L.; Ng, C.S.; Curry, J.L.; Joseph, R.W.; Alvarado, G.C.; Rohlfs, M.L.; Richard, J.; Gershenwald, J.E.; Kim, K.B.; et al. NRAS mutation status is an independent prognostic factor in metastatic melanoma. Cancer 2012, 118, 4014-4023. [CrossRef]

69. Pache, M.; Glatz, K.; Bösch, D.; Dirnhofer, S.; Mirlacher, M.; Simon, R.; Schraml, P.; Rufle, A.; Flammer, J.; Sauter, G.; et al. Sequence analysis and high-throughput immunohistochemical profiling of KIT (CD 117) expression in uveal melanoma using tissue microarrays. Virchows Arch. 2003, 443, 741-744. [CrossRef]

70. Gong, H.Z.; Zheng, H.Y.; Li, J. The clinical significance of KIT mutations in melanoma. Melanoma Res. 2018, 28, 259-270. [CrossRef]

71. Heinrich, M.C.; Corless, C.L.; Blanke, C.D.; Demetri, G.D.; Joensuu, H.; Roberts, P.J.; Eisenberg, B.L.; von Mehren, M.; Fletcher, C.D.; Sandau, K.; et al. Molecular correlates of imatinib resistance in gastrointestinal stromal tumors. J. Clin. Oncol. 2006, 24, 4764-4774. [CrossRef] [PubMed]

72. Chen, L.L.; Trent, J.C.; Wu, E.F.; Fuller, G.N.; Ramdas, L.; Zhang, W.; Raymond, A.K.; Prieto, V.G.; Oyedeji, C.O.; Hunt, K.K.; et al. A missense mutation in KIT kinase domain 1 correlates with imatinib resistance in gastrointestinal stromal tumors. Cancer Res. 2004, 64, 5913-5919. [CrossRef] [PubMed]

73. Chen, H.; Isozaki, K.; Kinoshita, K.; Ohashi, A.; Shinomura, Y.; Matsuzawa, Y.; Kitamura, Y.; Hirota, S. Imatinib inhibits various types of activating mutant kit found in gastrointestinal stromal tumors. Int. J. Cancer 2003, 105, 130-135. [CrossRef] [PubMed]

74. Carvajal, R.D.; Antonescu, C.R.; Wolchok, J.D.; Chapman, P.B.; Roman, R.; Teitcher, J.; Panageas, K.S.; Busam, K.J.; Chmielowski, B.; Lutzky, J.; et al. KIT as a Therapeutic Target in Metastatic Melanoma. JAMA 2011, 305, 2327-2334. [CrossRef] [PubMed]

75. Kalinsky, K.; Lee, S.; Rubin, K.; Lawrence, D.P.; Iafrarte, A.J.; Borger, D.R.; Margolin, K.A.; Leitao, M.M., Jr.; Tarhini, A.A.; Koon, H.B.; et al. A Phase II trial of Dasatinib in patients with locally advanced or stage IV mucosal, acral and vulvovaginal melanoma: A trial of the ECOG-ACRIN cancer research group (E2607). Cancer 2017, 123, 2688-2697. [CrossRef]

76. Mahalingam, M. NF1 and Neurofibromin: Emerging Players in the Genetic Landscape of Desmoplastic Melanoma. Adv. Anat. Pathol. 2017, 24,1-14. [CrossRef]

77. Rosenbaum, T.; Wimmer, K. Neurofibromatosis type 1 (NF1) and associated tumors. Klin. Padiatr. 2014, 226, 309-315. [CrossRef]

78. Nissan, M.H.; Pratilas, C.A.; Jones, A.M.; Ramirez, R.; Won, H.; Liu, C.; Tiwari, S.; Kong, L.; Hanrahan, A.J.; Yao, Z.; et al. Loss of NF1 in cutaneous melanoma is associated with RAS activation and MEK dependence. Cancer Res. 2014, 74, 2340-2350. [CrossRef]

79. Krauthammer, M.; Kong, Y.; Bacchiocchi, A.; Evans, P.; Pornputtapong, N.; Wu, C.; McCusker, J.P.; Ma, S.; Cheng, E.; Straub, R.; et al. Exome sequencing identifies recurrent mutations in NF1 and RASopathy genes in sun-exposed melanomas. Nat. Genet. 2015, 47, 996-1002. [CrossRef]

80. Kiuru, M.; Busam, K.J. The NF1 gene in tumor syndromes and melanoma. Lab. Investig. 2017, 97, $146-157$. [CrossRef]

81. Hintzsche, J.D.; Gorden, N.T.; Amato, C.M.; Kim, J.; Wuensch, K.E.; Robinson, S.E.; Applegate, A.J.; Couts, K.L.; Medina, T.M.; Wells, K.R.; et al. Whole-exome sequencing identifies recurrent SF3B1 R625 mutation and comutation of NF1 and KIT in mucosal melanoma. Melanoma Res. 2017, 27, 189-199. [CrossRef] [PubMed]

82. Wiesner, T.; Kiuru, M.; Scott, S.N.; Arcila, M.; Halpern, A.C.; Hollmann, T.; Berger, M.F.; Busam, K.J. NF1 Mutations Are Common in Desmoplastic Melanoma. Am. J. Surg. Pathol. 2015, 39, 1357-1362. [CrossRef] [PubMed]

83. Cosgarea, I.; Ugurel, S.; Sucker, A.; Livingstone, E.; Zimmer, L.; Ziemer, M.; Utikal, J.; Mohr, P.; Pfeiffer, C.; Pfohler, C.; et al. Targeted next generation sequencing of mucosal melanomas identifies frequent NF1 and RAS mutations. Oncotarget 2017, 8, 40683-40692. [CrossRef] [PubMed] 
84. Johnson, D.B.; Frampton, G.M.; Rioth, M.J.; Yusko, E.; Xu, Y.; Guo, X.; Ennis, R.C.; Fabrizio, D.; Chalmers, Z.R.; Greenbowe, J.; et al. Targeted next generation sequencing identifies markers of response to PD-1 blockade. Cancer Immunol. Res. 2016, 4, 959-967. [CrossRef]

85. Ersahin, T.; Tuncbag, N.; Cetin-Atalay, R. The PI3K/AKT/mTOR interactive pathway. Mol. Biosyst. 2015, 11, 1946-1954. [CrossRef]

86. Martini, M.; De Santis, M.C.; Braccini, L.; Gulluni, F.; Hirsch, E. PI3K/AKT signaling pathway and cancer: An updated review. Ann. Med. 2014, 46, 372-383. [CrossRef]

87. Polivka, J., Jr.; Janku, F. Molecular targets for cancer therapy in the PI3K/AKT/mTOR pathway. Pharmacol. Ther. 2014, 142, 164-175. [CrossRef]

88. Davies, M.A. The role of the PI3K-AKT pathway in melanoma. Cancer J. 2012, 18, 142-147. [CrossRef]

89. Kong, Y.; Si, L.; Li, Y.; Wu, X.; Xu, X.; Dai, J.; Tang, H.; Ma, M.; Chi, Z.; Sheng, X.; et al. Analysis of mTOR gene aberrations in melanoma patients and evaluation of their sensitivity to PI3K-AKT-mTOR pathway inhibitors. Clin. Cancer Res. 2016, 22, 1018-1027. [CrossRef]

90. Worby, C.A.; Dixon, J.E. Pten. Annu. Rev. Biochem. 2014, 83, 641-669. [CrossRef]

91. Hopkins, B.D.; Hodakoski, C.; Barrows, D.; Mense, S.M.; Parsons, R.E. PTEN function: The long and the short of it. Trends Biochem. Sci. 2014, 39, 183-190. [CrossRef] [PubMed]

92. Tsao, H.; Mihm, M.C., Jr.; Sheehan, C. PTEN expression in normal skin, acquired melanocytic nevi, and cutaneous melanoma. J. Am. Acad. Dermatol. 2003, 49, 865-872. [CrossRef]

93. Abdel-Rahman, M.H.; Yang, Y.; Zhou, X.P.; Craig, E.L.; Davidorf, F.H.; Eng, C. High frequency of submicroscopic hemizygous deletion is a major mechanism of loss of expression of PTEN in uveal melanoma. J. Clin. Oncol. 2006, 24, 288-295. [CrossRef] [PubMed]

94. Schopf, F.H.; Biebl, M.M.; Buchner, J. The HSP90 chaperone machinery. Nat. Rev. Mol. Cell Biol. 2017, 18, 345-360. [CrossRef] [PubMed]

95. Li, J.; Buchner, J. Structure, function and regulation of the hsp90 machinery. Biomed. J. 2013, 36, $106-117$. [PubMed]

96. Sharma, S.; Agatsuma, T.; Nakano, H. Targeting of the protein chaperone, HSP90, by the transformation suppressing agent, radicicol. Oncogene 1998, 16, 2639.e45. [CrossRef] [PubMed]

97. Becker, B.; Multhoff, G.; Farkas, B.; Wild, P.J.; Landthaler, M.; Stolz, W.; Vogt, T. Induction of Hsp90 protein expression in malignant melanomas and melanoma metastases. Exp. Dermatol. 2004, 13, 27-32. [CrossRef]

98. Tas, F.; Bilgin, E.; Erturk, K.; Duranyildiz, D. Clinical Significance of Circulating Serum Cellular Heat Shock Protein 90 (HSP90) Level in Patients with Cutaneous Malignant Melanoma. Asian Pac. J. Cancer Prev. 2017, 18, 599-601.

99. Faingold, D.; Marshall, J.; Antecka, E.; Di Cesare, S.; Odashiro, A.; Bakalian, S.; Fernandes, B.F.; Burnier, M.N., Jr. Immune expression and inhibition of heat shock protein 90 in uveal melanoma. Clin. Cancer Res. 2008, 14, 847-855. [CrossRef]

100. Shah, S.; Luke, J.J.; Jacene, H.A.; Chen, T.; Giobbie-Hurder, A.; Ibrahim, N.; Buchbinder, E.L.; McDermott, D.F.; Flaherty, K.T.; Sullivan, R.J.; et al. Results from phase II trial of HSP90 inhibitor, STA-9090 (ganetespib), in metastatic uveal melanoma. Melanoma Res. 2018, 28, 605-610. [CrossRef]

101. Eberle, J.; Hossini, A.M. Expression and Function of Bcl-2 Proteins in Melanoma. Curr. Genom. 2008, 9, 409-419. [CrossRef] [PubMed]

102. Prasad, M.L.; Patel, S.G.; Shah, J.P.; Hoshaw-Woodard, S.; Busam, K.J. Prognostic significance of regulators of cell cycle and apoptosis, p16(INK4a), p53, and bcl-2 in primary mucosal melanomas of the head and neck. Head Neck Pathol. 2012, 6, 184-190. [CrossRef] [PubMed]

103. Jiang, Z.; Yu, F.; Li, M. Upregulation of BCL2 19 kD Protein-Interacting Protein 3 (BNIP3) is Predictive of Unfavorable Prognosis in Uveal Melanoma. Med. Sci. Monit. 2018, 24, 4711-4717. [CrossRef] [PubMed]

104. Anvekar, R.A.; Asciolla, J.J.; Missert, D.J.; Chipuk, J.E. Born to be alive: A role for the BCL-2 family in melanoma tumor cell survival, apoptosis, and treatment. Front. Oncol. 2011, 1, 34. [CrossRef] [PubMed]

105. Heidenreich, B.; Kumar, R. TERT promoter mutations in telomere biology. Mutat. Res. 2017, 771, $15-31$. [CrossRef]

106. Bell, R.J.; Rube, H.T.; Xavier-Magalhães, A.; Costa, B.M.; Mancini, A.; Song, J.S.; Costello, J.F. Understanding TERT Promoter Mutations: A Common Path to Immortality. Mol. Cancer Res. 2016, 14, 315-323. [CrossRef] 
107. Swaminathan, S.S.; Field, M.G.; Sant, D.; Wang, G.; Galor, A.; Dubovy, S.R.; Harbour, J.W.; Karp, C.L. Molecular Characteristics of Conjunctival Melanoma Using Whole-Exome Sequencing. JAMA Ophthalmol. 2017, 135, 1434-1437. [CrossRef]

108. Ikehata, H. Mechanistic considerations on the wavelength-dependent variations of UVR genotoxicity and mutagenesis in skin: The discrimination of UVA-signature from UV-signature mutation. Photochem. Photobiol. Sci. 2018, 17, 1861-1871. [CrossRef]

109. Horn, S.; Figl, A.; Rachakonda, P.S.; Fischer, C.; Sucker, A.; Gast, A.; Kadel, S.; Moll, I.; Nagore, E.; Hemminki, K.; et al. TERT promoter mutations in familial and sporadic melanoma. Science 2013, 339, 959-961. [CrossRef]

110. Hugdahl, E.; Kalvenes, M.B.; Mannelqvist, M.; Ladstein, R.G.; Akslen, L.A. Prognostic impact and concordance of TERT promoter mutation and protein expression in matched primary and metastatic cutaneous melanoma. Br. J. Cancer 2018, 118, 98-105. [CrossRef]

111. Liang, W.S.; Hendricks, W.; Kiefer, J.; Schmidt, J.; Sekar, S.; Carpten, J.; Craig, D.W.; Adkins, J.; Cuyugan, L.; Manojlovic, Z.; et al. Integrated genomic analyses reveal frequent TERT aberrations in acral melanoma. Genome Res. 2017, 27, 524-532. [CrossRef] [PubMed]

112. Mikkelsen, L.H.; Larsen, A.C.; von Buchwald, C.; Drzewiecki, K.T.; Prause, J.U.; Heegaard, S. Mucosal malignant melanoma-A clinical, oncological, pathological and genetic survey. APMIS 2016, 124, 475-486. [CrossRef] [PubMed]

113. Roth, A.; Harley, C.B.; Baerlocher, G.M. Imetelstat (GRN163L)-Telomerase-based cancer therapy. Recent Results Cancer Res. 2010, 184, 221-234. [PubMed]

114. Low, K.C.; Tergaonkar, V. Telomerase: Central regulator of all of the hallmarks of cancer. Trends Biochem. Sci. 2013, 38, 426-434. [CrossRef] [PubMed]

115. Jiao, Y.; Feng, Y.; Wang, X. Regulation of Tumor Suppressor Gene CDKN2A and Encoded p16-INK4a Protein by Covalent Modifications. Biochemistry 2018, 83, 1289-1298. [CrossRef] [PubMed]

116. Casula, M.; Paliogiannis, P.; Ayala, F.; De Giorgi, V.; Stanganelli, I.; Mandalà, M.; Colombino, M.; Manca, A.; Sini, M.C.; Caracò, C.; et al. Germline and somatic mutations in patients with multiple primary melanomas: A next generation sequencing study. BMC Cancer 2019, 19, 772. [CrossRef]

117. Read, J.; Wadt, K.A.; Hayward, N.K. Melanoma genetics. J. Med. Genet. 2016, 53, 1-14. [CrossRef]

118. Kong, Y.; Sheng, X.; Wu, X.; Yan, J.; Ma, M.; Yu, J.; Si, L.; Chi, Z.; Cui, C.; Dai, J.; et al. Frequent Genetic Aberrations in the CDK4 Pathway in Acral Melanoma Indicate the Potential for CDK4/6 Inhibitors in Targeted Therapy. Clin. Cancer Res. 2017, 23, 6946-6957. [CrossRef]

119. Hsieh, R.; Nico, M.M.; Coutinho-Camillo, C.M.; Buim, M.E.; Sangueza, M.; Lourenço, S.V. The CDKN2A and MAP kinase pathways: Molecular roads to primary oral mucosal melanoma. Am. J. Dermatopathol. 2013, 35, 167-175. [CrossRef]

120. Abdel-Rahman, M.H.; Pilarski, R.; Massengill, J.B.; Christopher, B.N.; Noss, R.; Davidorf, F.H. Melanoma candidate genes CDKN2A/p16/INK4A, p14ARF, and CDK4 sequencing in patients with uveal melanoma with relative high-risk for hereditary cancer predisposition. Melanoma Res. 2011, 21, 175-179. [CrossRef]

121. Harper, J.W.; Adami, G.R.; Wei, N.; Keyomarsi, K.; Elledge, S.J. The p21 Cdk-interacting protein Cip1 is a potent inhibitor of G1 cyclin-dependent kinases. Cell 1993, 75, 805-816. [CrossRef]

122. Rossi, E.; Bagalà, C.; Inzani, F.; Leoncini, E.; Brunelli, C.; Lanza, P.; Basso, M.; Mattiucci, G.C.; Cassano, A.; Rindi, G.; et al. RUNX3 as a Potential Predictor of Metastasis in Human Pancreatic Cancer. In Vivo 2017, 31, 833-840. [PubMed]

123. Takahashi, M.; Shimodaira, H.; Andreutti-Zaugg, C.; Iggo, R.; Kolodner, R.D.; Ishioka, C. Functional analysis of human MLH1 variants using yeast and in vitro mismatch repair assays. Cancer Res. 2007, 67, 4595-4604. [CrossRef] [PubMed]

124. Parsons, M.T.; Buchanan, D.D.; Thompson, B.; Young, J.P.; Spurdle, A.B. Correlation of tumour BRAF mutations and MLH1 methylation with germline mismatch repair (MMR) gene mutation status: A literature review assessing utility of tumour features for MMR variant classification. J. Med. Genet. 2012, 49, 151-157. [CrossRef]

125. Zurac, S.; Neagu, M.; Constantin, C.; Cioplea, M.; Nedelcu, R.; Bastian, A.; Popp, C.; Nichita, L.; Andrei, R.; Tebeica, T.; et al. Variations in the expression of TIMP1, TIMP2 and TIMP3 in cutaneous melanoma with regression and their possible function as prognostic predictors. Oncol. Lett. 2016, 11, 3354-3360. [CrossRef] 
126. Kenawy, N.; Kalirai, H.; Sacco, J.J.; Lake, S.L.; Heegaard, S.; Larsen, A.C.; Finger, P.T.; Milman, T.; Chin, K.; Mosci, C.; et al. Conjunctival melanoma copy number alterations and correlation with mutation status, tumor features, and clinical outcome. Pigment Cell Melanoma Res. 2019, 32, 564-575. [CrossRef]

127. Rossi, E.; Pagliara, M.M.; Orteschi, D.; Dosa, T.; Sammarco, M.G.; Caputo, C.G.; Petrone, G.; Rindi, G.; Zollino, M.; Blasi, M.A.; et al. Pembrolizumab as first-line treatment for metastatic uveal melanoma. Cancer Immunol. Immunother. 2019, 68, 1179-1185. [CrossRef]

128. Yamagishi, M.; Uchimaru, K. Targeting EZH2 in cancer therapy. Curr. Opin. Oncol. 2017, $29,375-381$. [CrossRef]

129. Mahmoud, F.; Shields, B.; Makhoul, I.; Hutchins, L.F.; Shalin, S.C.; Tackett, A.J. Role of EZH2 histone methyltrasferase in melanoma progression and metastasis. Cancer Biol. Ther. 2016, 17, 579-591. [CrossRef]

130. Tiffen, J.C.; Gallagher, S.J.; Tseng, H.Y.; Filipp, F.V.; Fazekas de St Groth, B.; Hersey, P. EZH2 as a mediator of treatment resistance in melanoma. Pigment Cell Melanoma Res. 2016, 29, 500-507. [CrossRef]

131. Esquela-Kerscher, A.; Slack, F.J. Oncomirs-Micrornas with a role in cancer. Nat. Rev. Cancer 2006, 6, $259-269$. [CrossRef] [PubMed]

132. Finnegan, E.F.; Pasquinelli, A.E. MicroRNA biogenesis: Regulating the regulators. Crit. Rev. Biochem. Mol. Biol. 2013, 48, 51-68. [CrossRef] [PubMed]

133. Zhang, B.; Pan, X.; Cobb, G.P.; Anderson, T.A. MicroRNAs as oncogenes and tumor suppressors. Dev. Biol. 2007, 302, 1-12. [CrossRef] [PubMed]

134. Kunz, M. MicroRNAs in melanoma biology. Adv. Exp. Med. Biol. 2013, 774, 103-120.

135. Ross, C.L.; Kaushik, S.; Valdes-Rodriguez, R.; Anvekar, R. MicroRNAs in cutaneous melanoma: Role as diagnostic and prognostic biomarkers. J. Cell Physiol. 2018, 233, 5133-5141. [CrossRef]

136. Xu, Y.; Brenn, T.; Brown, E.R.; Doherty, V.; Melton, D.W. Differential expression of microRNAs during melanoma progression: $\mathrm{miR}-200 \mathrm{c}, \mathrm{miR}-205$ and miR-211 are downregulated in melanoma and act as tumour suppressors. Br. J. Cancer 2012, 106, 553-561. [CrossRef]

137. Forloni, M.; Dogra, S.K.; Dong, Y.; Conte, D., Jr.; Ou, J.; Zhu, L.J.; Deng, A.; Mahalingam, M.; Green, M.R.; Wajapeyee, N. miR-146a promotes the initiation and progression of melanoma by activating Notch signaling. Elife 2014, 3, e01460. [CrossRef]

138. Philippidou, D.; Schmitt, M.; Moser, D.; Margue, C.; Nazarov, P.V.; Muller, A.; Vallar, L.; Nashan, D.; Behrmann, I.; Kreis, S. Signatures of microRNAs and selected microRNA target genes in human melanoma. Cancer Res. 2010, 70, 4163-4173. [CrossRef]

139. Streicher, K.L.; Zhu, W.; Lehmann, K.P.; Georgantas, R.W.; Morehouse, C.A.; Brohawn, P.; Carrasco, R.A.; Xiao, Z.; Tice, D.A.; Higgs, B.W.; et al. A novel oncogenic 1 role for the miRNA-506-514 cluster in initiating melanocyte transformation and promoting melanoma growth. Oncogene 2012, 31, 1558-1570. [CrossRef]

140. Smit, K.N.; Chang, J.; Derks, K.; Vaarwater, J.; Brands, T.; Verdijk, R.M.; Wiemer, E.A.C.; Mensink, H.W.; Pothof, J.; de Klein, A.; et al. Aberrant MicroRNA expression and its implications for uveal melanoma metastasis. Cancers 2019, 11, 815. [CrossRef]

(C) 2019 by the authors. Licensee MDPI, Basel, Switzerland. This article is an open access article distributed under the terms and conditions of the Creative Commons Attribution (CC BY) license (http://creativecommons.org/licenses/by/4.0/). 